\title{
Influence of Land Use Activities on Riparian Vegetation, Soil and Water Quality: An Indicator of Biodiversity Loss, South West Mau Forest, Kenya
}

\author{
Naomi Njue, Eric Koech, Joseph Hitimana, Peter Sirmah* \\ School of Natural Resource and Environmental Management, University of Kabianga, Kericho, Kenya \\ Email: *sirmahkipkosgei110@hotmail.com
}

How to cite this paper: Njue, N., Koech, E., Hitimana, J., \& Sirmah, P. (2016) Influence of Land Use Activities on Riparian Vegetation, Soil and Water Quality: An Indicator of Biodiversity Loss, South West Mau Forest, Kenya. Open Journal of Forestry, 6, 373385.

http://dx.doi.org/10.4236/ojf.2016.65030

Received: March 31, 2016

Accepted: September 2, 2016

Published: September 5, 2016

Copyright $\odot 2016$ by authors and Scientific Research Publishing Inc. This work is licensed under the Creative Commons Attribution International License (CC BY 4.0).

http://creativecommons.org/licenses/by/4.0/

c) (i) Open Access

\begin{abstract}
Watershed and riparian areas of Mau Forest Complex in Kenya are experiencing increased threats due to unsustainable land use activities geared towards economic growth amidst growing population. This study was carried out to examine effects of land use activities on riparian vegetation, soil and water quality along two major rivers (Chemosit and Kipsonoi) of South West Mau Forest (SWMF). Land use activities adjacent to these rivers and biodiversity disturbance on the riparian zone were identified and underpinned to changes on Total Nitrogen, Total Phosphorous, Potassium, Sulphur, Cadmium, Copper, Lead, Total Suspended Solids and soil Organic Carbon. Three sampling sites designated(upstream, midstream and downstream) were identified and established along each river as guided by existing land use activities represented by forest, tea plantation and mixed agricultural farming respectively. At each sampling site, a $200 \mathrm{~m} \times 50 \mathrm{~m}$ section was systematically marked on each side of the river bank; the longest side being parallel to the river flow and divided into three belts transects each $20 \mathrm{~m} \times 50 \mathrm{~m}$, spaced $70 \mathrm{~m}$ apart. Six distinct land use activities (indigenous forest, food crop, tree and tea farming, livestock keeping and urban settlement) were identified as the major land use activities in SWMF. Plant species richness decreased and overall riparian disturbance increased from upstream (intact canopy with native vegetation) to mid-stream and downstream as epitomized by the structure, biodiversity disturbance resulting from extensive and intensive farming, intrusion of exotic species to livestock grazing and urban settlement. Variation among sampling sites in Total Suspended Solids, $\mathrm{pH}$, Total Nitrogen, Phosphorus and Potassium were associated to different land use activities along the riparian zone. Total Nitrogen and water $\mathrm{pH}$ showed significant sensitivity to land use changes $(p<0.05)$. Put together these results indicate loss of biodiversity, riparian disturbance hence a need to adopt environmental-friendly land use planning and sustainable farming systems in SWMF.
\end{abstract}




\section{Keywords}

Mau Forest, Riparian Vegetation, Kenya

\section{Introduction}

Watershed degradation in the developing countries due to anthropogenic activities is increasingly becoming a threat to the natural water resources (GoK, 2009; Mati et al., 2008). As a result, most rural areas are undergoing rapid and far reaching land use changes. Many researchers including Olson and Matina (2006) concur that most of the changes are mainly associated with intensification of agriculture and expansion of mixed-crop livestock systems into former grazing land and other natural areas. In addition there is increased deforestation and encroachment of the forests hence reduced forest cover (Enanga et al., 2011).

Changes in land use patterns in Kenya are linked to a rapidly increasing population in rural areas (Mira, 2004). This growth rate translates to an increased pressure and demand for land resources especially in the watershed regions such as Mau Forest Complex. As a result, there is continuing watershed degradation reflected through diminishing forest cover, reduced water quality, soil productivity, loss of riparian vegetation and wetland areas leading to a decline in the ecological stability of these systems (Matano et al., 2015).

SWMFC is considered the most important of the five main watershed areas in Kenya because of its immense economic, social and environmental contributions to the country (GoK, 2009). It is the main source of Chemosit and Kipsonoi rivers among other major rivers that drain into the Lake Victoria Basin. Despite the critical role in supporting environmental, socio-economic and biological processes, South West Mau Forest Complex has been greatly deforested through excision and encroachment for settlement and farmland (Gok, 2009; Kinyanjui, 2009). This high rate of vegetation loss has led to decline in the ecological and hydrological changes that may threaten the sustainable future of areas downstream, biodiversity conservation and livelihood support systems (Litman, 2011; Masese et al., 2011).

Riparian areas are essential for diminishing negative impacts of land use activities on rivers (Mitsch \& Day, 2006; Enanga et al., 2011). However, the riparian areas in SWMFC are experiencing diverse development initiatives likely to have also considerably reduced the biodiversity and increased threats to these river systems (GoK, 2009). This study set out to determine how land use activities have affected riparian structure, water and soil qualities along Chemosit and Kipsonoi rivers in South West Mau Forest Complex.

\section{Materials and Methods}

\subsection{The Study Site}

This study was carried out along Chemosit and Kipsonoi rivers in South West Mau 
Forest Complex (SWMFC). It lies at $0.14^{\circ}-0.78^{\circ}$ South and $35.28^{\circ}-35.70^{\circ}$ West at an altitude ranging from $1600 \mathrm{~m}-3000 \mathrm{~m}$ above sea level (Kinyanjui, 2009). Kipsonoi river extends from the South Western Mau main escarpment, flows through Sotik and finally drains to Sondu river. On the other hand, Chemosit river, flows through Kimulot, Itare, and Nyakach before entering Lake Victoria (Calamari et al., 1995) (Figure 1).

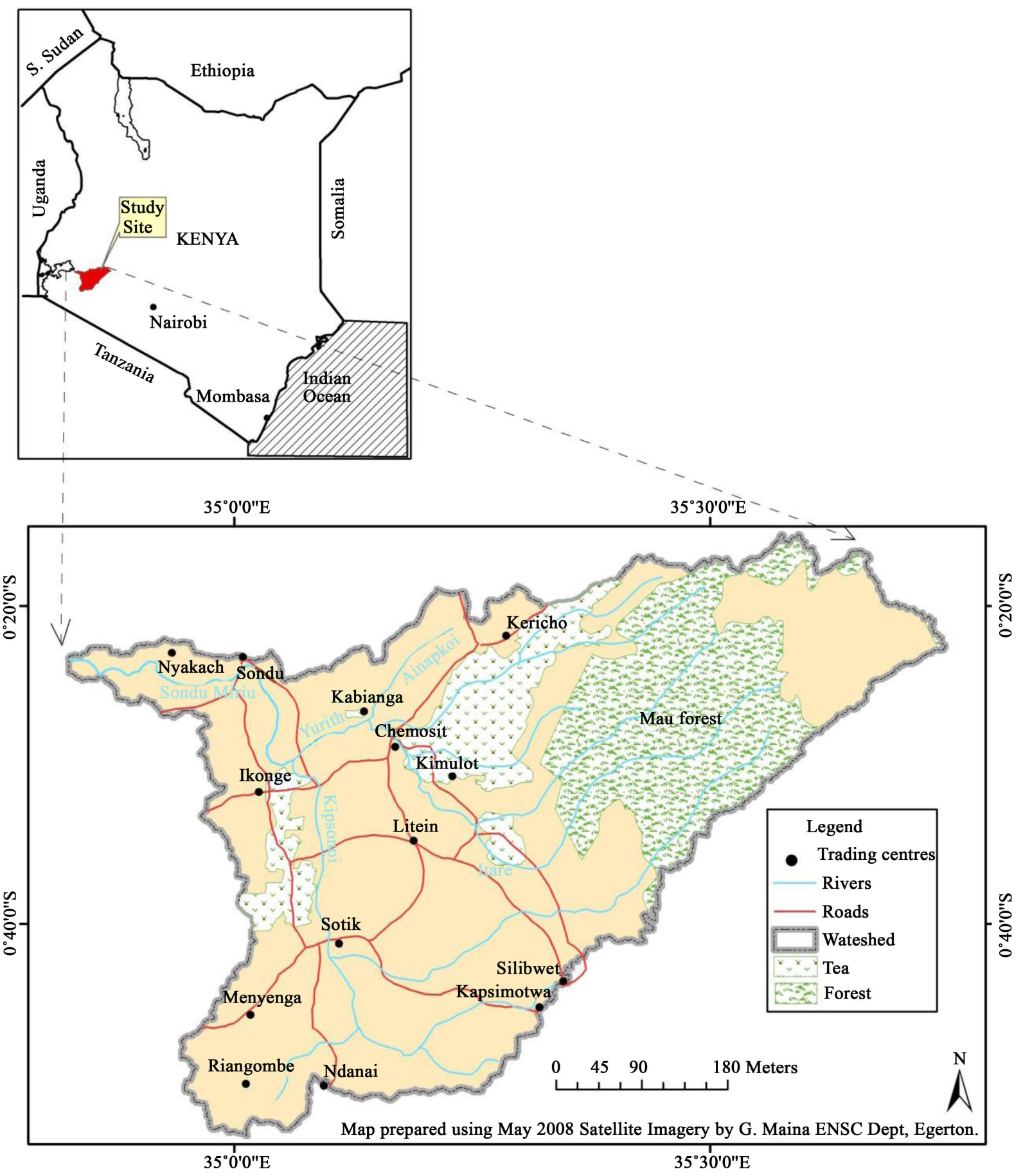

Figure 1. Satellite imagery of study sites (Ouma et al., 2013). 
The area receives conventional type of rainfall generally exhibiting bimodal pattern which is well distributed throughout the year with an average rainfall of $1000 \mathrm{~mm}$ to $2000 \mathrm{~mm} \cdot \mathrm{yr}^{-1}$ with the highland areas receiving cumulative annual rainfall of approximately $1835 \mathrm{~mm}$ which decreases to about $1500 \mathrm{~mm} \cdot \mathrm{yr}^{-1}$ towards the lowlands. There is a short dry spell in January and February while April and May are the wettest months and short rains in November and December. The temperatures in the area range from $18^{\circ} \mathrm{C}$ to $22^{\circ} \mathrm{C}$ with the lowland having an annual temperature of $26^{\circ} \mathrm{C}$. July is the coldest month with an average of $16^{\circ} \mathrm{C}$ while February is hottest with average temperatures of $20^{\circ} \mathrm{C}$ (GoK, 2009).

\subsection{The Study Design}

Three Sampling sites (designated upstream, midstream and downstream) were identified to represent different predominant land uses along each river as guided by existing land use activities represented by forest, tea plantation and mixed agricultural farming respectively as follows: Chemosit river \{Itare, Chemosit bridge, Kipranye bridge\} and Kipsonoi rivers \{Bosto, Chebilat bridge, Sondu bridge\}. Sampling sites were restricted to a $200 \mathrm{~m}$ long upstream section of the river on either side of the bank and near bridges to enhance accessibility. In addition, sampling was started $30 \mathrm{~m}$ away from the bridge and forest margins to avoid edge effects.

In each of the sampling site, 3 water sampling points were identified at an interval of $100 \mathrm{~m}$. For soil sampling 3 belt transects $(50 \mathrm{~m} \times 20 \mathrm{~m}$ ) were laid systematically on both sides of the river bank at an interval of $70 \mathrm{~m}$ apart. The transects were laid perpendicular to the river flow to encompass the most heterogeneity (Stohlgren et al., 1995). In each transect, plots were created according to a modified procedure developed by $\mathrm{Hi}$ timana et al. (2004). The belts were subdivided into 5 contiguously units of $10 \mathrm{~m} \times 20$ $\mathrm{m}$ sampling plots. $2 \mathrm{~m} \times 10 \mathrm{~m}$ nested sampling units were established within each 0.02 ha plots. The same sampling design was adopted in all sampling sites along the two rivers.

\subsubsection{Water and Soil Sample Collections}

Water sampling was done from the middle and the two edges of the river bank. This was replicated 3 times at every $100 \mathrm{~m}$ section of the river. On the other hand, soil samples were collected diagonally in 0.02 ha plots transects at $10 \mathrm{~cm}$ depth and at the $1^{\text {st }}(10$ $\mathrm{m}), 3^{\text {rd }}(30 \mathrm{~m})$ and $5^{\text {th }}(50 \mathrm{~m}) 0.02$ ha plots created in each transect from the edge of river. Soil was scooped, packed in well labeled transparent polythene bags. A total of 108 samples ( 3 sites $\times 18$ replicates of sample plots $\times 2$ river systems) were collected for analysis.

\subsubsection{Land Use Activities Adjacent to River Systems}

Adjacent land use activities were obtained through direct observation and photographs. Information on major crops was collected using a structured questionnaire administered to the sampled households living in the immediate vicinity and within $1 \mathrm{~km}$ on either side of the river bank. Local land use in every sampling site was recorded. 


\subsection{Physical and Chemical Analysis of Water}

Physical parameters (Total Suspended Solids), chemical parameters (pH, Total Nitrogen, Total Phosphorous and Total Potassium) and heavy metals (Copper, Cadmium and Lead) was done according to the standard procedures as described in APHA (1998). These are as follows: Total suspended solids were estimated gravimetrically, water $\mathrm{pH}$ using a $\mathrm{pH}$ meter, Total Nitrogen determined by Kjeldahl digestion. Total phosphorous was determined using the ascorbic acid method (APHA, 1995) while analysis for potassium, copper, cadmium and lead was carried out using Atomic Absorption Spectrophotometer (AAS). Before analysis, calibration standards of different concentrations were prepared. In this particular analysis, each replica representing samples from the middle and the two edges were mixed separately to form a composite sample. A total of 18 composite samples were obtained for the entire water samples collected.

\subsection{Physical and Chemical Analysis of Soil}

Soil samples were separately air-dried at room temperature, crushed, homogenized and passed through a $2 \mathrm{~mm}$ sieve. Soil organic carbon content was determined by the WalkeyBlack titration method (Nelson \& Sommers, 1982). Total Nitrogen was determined using the Kjeldahl distillation method (Okalebo et al., 2002). Potassium, Sulphur, Phosphorous, Cadmium, Copper, and Lead were analyzed using inductivity couple plasma spectrophotometer (ICPS). Soil $\mathrm{pH}$ was determined using a $\mathrm{pH}$ meter.

\section{Results and Discussions}

\subsection{Land Use Activities Adjacent to Chemosit and Kipsonoi Rivers}

Table 1 below shows the major land use activities adjacent to each of the two rivers.

Chemosit and Kipsonoi rivers traverses through different land use types. In this case, six distinct land use activities were identified along based on their dominant land uses and characteristics. Generally there is a variation in land use activities from upstream to downstream. Upstream is dominated by indigenous forest characterized by dense

Table 1. Land use activities adjacent to Chemosit and Kipsonoi rivers.

\begin{tabular}{|c|c|c|c|}
\hline Study sites & Sampling sites & Major land use activities & Major crops \\
\hline \multirow{3}{*}{$\begin{array}{l}\text { Chemosit } \\
\text { river }\end{array}$} & Upstream & Indigenous Forest & None \\
\hline & Midstream & $\begin{array}{l}\text { Tea growing, tree farming, food crop, } \\
\text { livestock keeping and urban land. }\end{array}$ & $\begin{array}{c}\text { Tea, maize, bananas, beans and pi- } \\
\text { neapples }\end{array}$ \\
\hline & Downstream & $\begin{array}{c}\text { Food crop farming, tree farming } \\
\text { and livestock keeping }\end{array}$ & $\begin{array}{l}\text { Maize, pineapples, } \\
\text { beans and bananas }\end{array}$ \\
\hline \multirow{3}{*}{$\begin{array}{l}\text { Kipsonoi } \\
\text { river }\end{array}$} & Upstream & Indigenous Forest & None \\
\hline & Midstream & $\begin{array}{l}\text { Food crop farming, tree farming, } \\
\text { livestock keeping and urban land }\end{array}$ & $\begin{array}{l}\text { Bananas, maize, kales, } \\
\text { finger millet, sorghum and beans }\end{array}$ \\
\hline & Downstream & $\begin{array}{l}\text { Food crop farming, tree planting, } \\
\text { livestock keeping and urban land. }\end{array}$ & Sugarcane, maize and beans \\
\hline
\end{tabular}


network of trees and bushes with little human disturbance. From the edge of the forests towards midstream, the land opens up to a rich upland agricultural area of extensive and intensive farming characterized by tea plantation and few human settlements. Moving downstream, grazing and mixed agricultural farming predominate with more permanently settled small scale farmers and urban set-up with high population and economic activities. From our results, farming plays an important role in South West Mau catchment and is in agreement with findings by Calamari et al., 1995; Jaetzold and Schmidt, 2009.

Figure 2 reports the overall riparian biodiversity disturbance in South West Mau catchment.

Upstream riparian vegetation was least disturbed with native vegetation present on both sides of the river, intact canopy and with continuous woody vegetation along the riparian zone, dense ground cover and river banks in natural condition. Midstream riparian vegetation is in poor condition characterized by isolated woody vegetation, limited ground cover and disturbed banks. In addition there is a high disturbance of the riparian zone by stock or through the intrusion of exotic species, although some native species remain. Valley vegetation is clearly agriculture with native vegetation clearly disturbed and with a high percentage of introduced species present. Downstream riparian vegetation is severely disturbed on both sides as indicated by reduced and absence of riparian vegetation.

\subsection{Effect of the Land Use Activities on Water Quality}

The mean values and standard deviation of water physico-chemical variables at different sampling sites along the two rivers of Chemosit and Kipsonoi are presented in Table 2 below.

Table 2. Mean concentration levels and standard errors $( \pm)$ of nutrients, total suspended solids and heavy metals along Chemosit $\left({ }^{\mathrm{c}}\right)$ and Kipsonoi $\left({ }^{\mathrm{k}}\right)$ rivers.

\begin{tabular}{cccc}
\hline Physico-chemical water parameters & Upstream & Midstream & Downstream \\
\hline Total SS (mg/l) & ${ }^{\mathrm{c}} 45.39 \pm 10.98$ & $84.33 \pm 19.68$ & $40.50 \pm 9.96$ \\
& ${ }^{\mathrm{k}} 24.89 \pm 6.43$ & $72.61 \pm 23.85$ & $64.56 \pm 13.31$ \\
pH & ${ }^{\mathrm{c}} 7.01 \pm 0.94^{\mathrm{a}}$ & $7.17 \pm 0.59^{\mathrm{ab}}$ & $6.53 \pm 0.10^{\mathrm{b}}$ \\
& ${ }^{\mathrm{k}} 7.04 \pm 0.05^{\mathrm{ab}}$ & $6.91 \pm 0.07^{\mathrm{a}}$ & $7.22 \pm 0.07^{\mathrm{ab}}$ \\
Total Nitrogen (mg/l) & ${ }^{\mathrm{c}} 3.73 \pm 0.52^{\mathrm{a}}$ & $6.74 \pm 0.74^{\mathrm{b}}$ & $5.48 \pm 0.83^{\mathrm{ab}}$ \\
& ${ }^{\mathrm{k}} 5.18 \pm 0.68^{\mathrm{b}}$ & $5.70 \pm 0.48^{\mathrm{b}}$ & $2.70 \pm 0.75^{\mathrm{a}}$ \\
Total Phosphorus (mg/l) & ${ }^{\mathrm{c}} 0.03 \pm 0.01$ & $0.06 \pm 0.01$ & $0.04 \pm 0.01$ \\
& ${ }^{\mathrm{k}} 0.04 \pm 0.07$ & $0.06 \pm 0.01$ & $0.06 \pm 0.01$ \\
Potassium (mg/l) & ${ }^{\mathrm{c}} 1.63 \pm 0.06$ & $1.55 \pm 0.35$ & $1.56 \pm 0.54$ \\
& ${ }^{\mathrm{k}} 1.63 \pm 0.03$ & $1.78 \pm 0.02$ & $1.58 \pm 0.09$ \\
Cadmium (mg/l) & ${ }^{\mathrm{c}} 1.26 \pm 0.30$ & $0.48 \pm 0.80$ & $1.35 \pm 0.74$ \\
& ${ }^{\mathrm{k}} 2.04 \pm 0.51$ & $1.41 \pm 0.7$ & $2.08 \pm 0.51$ \\
Copper (mg/l) & ${ }^{\mathrm{c}} 1.53 \pm 1.01$ & $3.38 \pm 1.44$ & $3.84 \pm 0.52$ \\
& ${ }^{\mathrm{k}} 2.45 \pm 1.81$ & $2.57 \pm 0.40$ & $0.63 \pm 0.23$ \\
Lead (mg/l) & ${ }^{\mathrm{c}} 0.80 \pm 0.32$ & $1.28 \pm 0.64$ & $1.02 \pm 0.50$ \\
& ${ }^{\mathrm{k}} 0.71 \pm 0.33$ & $1.15 \pm 0.58$ & $1.15 \pm 0.58$ \\
\hline
\end{tabular}

${ }^{* a, b, a b}$ Means with different superscripts in the same row are significantly different at $p<0.05$ (Data analyzed by Tukey's test). 


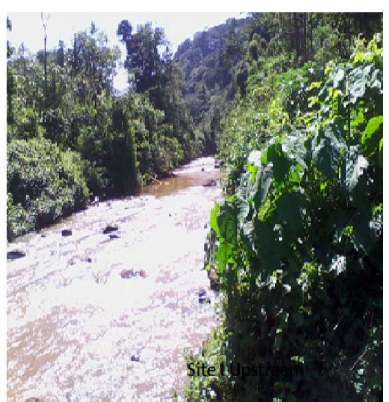

Upstream

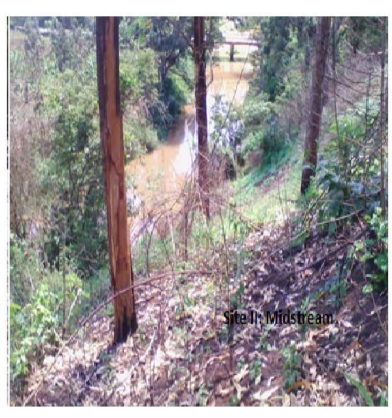

Midstream

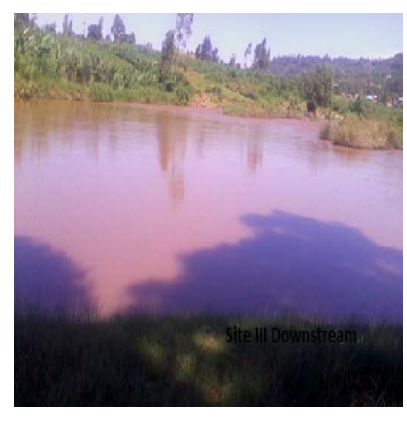

Downstream

Figure 2. Overall riparian biodiversity disturbance.

During the study period, significant differences were observed in Water $\mathrm{pH}$ and Total Nitrogen between sampling sites. Tukey's test showed that the mean water $\mathrm{pH}$ at upstream sampling site differed significantly from that recorded at downstream of Chemosit river. Along Kipsonoi river, the mean water $\mathrm{pH}$ differed significantly between midstream and Downstream sampling sites. In both rivers, the mean value for water $\mathrm{pH}$ ranged from 6.9 (slightly acidic) to 7.2 (slightly alkaline). However these values fall within the $\mathrm{pH}$ range associated with most natural waters of 6.5 to 8.5 (World Health Organization, 2000). Most ecosystems are sensitive to changes in $\mathrm{pH}$ while certain organisms prefer different ranges of $\mathrm{pH}$ (Kinyua \& Pacini, 1991). The reported land use activities in SWMF do not seem to modify the $\mathrm{pH}$ of the water. Indeed soils and land use activities affect the proportion of major ions in water bodies and hence the water pH (Bailey et al., 1994).

On the other hand, along Chemosit river significant differences were observed in total nitrogen between upstream and midstream sampling sites and between upstream and downstream along Kipsonoi river, respectively. The high Total Nitrogen concentrations of $6.7 \mathrm{mg} / \mathrm{l}$ and $5.7 \mathrm{mg} / \mathrm{l}$ observed midstream of the two rivers could be associated with adjacent urban and agricultural land use activities. According to (FAO, 1996) agricultural activities can lead to an increased flux of nitrogen into water bodies while use of fertilizers on agricultural land has been associated to high nutrient levels at such sites (Wu et al., 2006).

Further, total suspended solids, potassium, total phosphorous, cadmium, lead and copper did not however show any significant differences. Total Suspended Solids were highest midstream on both rivers. This variation could be associated to the different land use activities reported for these sites, run-off from agriculture, soil erosion as well as in- stream activities such as car washing. Presence of indigenous forests, absence of agricultural activities, intact riparian zones characterized by dense vegetation explain the low levels of Total Suspended Solids in the upstream of the two rivers (Andrea et al., 2009; Masese et al., 2011). However total suspended solids in SWMF ranged from 24 - $84 \mathrm{mg} / \mathrm{l}$ which is below WHO (2000) limits of $1000 \mathrm{mg} / \mathrm{l}$ of suspended solids of drinking water.

Total phosphorous concentrations increased downstream with the highest concentration recorded at midstream and lowest at upstream on both rivers. Natural concen- 
trations of phosphorous in surface waters usually range from 0.005 to $0.02 \mathrm{mg} / \mathrm{l}$, while the Environmental Protection Agency (EPA) recommends a $0.1 \mathrm{mg} / \mathrm{l}$ for aquatic systems to prevent accelerated eutrophication (Buda et al., 2010). Low concentrations of total phosphorus $(0.03 \mathrm{mg} / \mathrm{l}$ and $0.04 \mathrm{mg} / \mathrm{l})$ recorded upstream of Chemosit and Kipsonoi rivers is linked to the undisturbed dense network of trees. In undisturbed forested areas, streams are believed to have good water quality with low concentration of nutrients (Andrea et al., 2009). The dense riparian vegetation within the forest land use are effective buffers in filtering out most of the nutrients from the surface run-off (Enanga et al., 2011). These findings mirror previous studies that concluded that water quality is greatly linked to land use in a catchment (Triest et al., 2012) and confirms several studies that have shown agriculture and urban land use as a primary predictor for nitrogen and phosphorous in stream water (Ahearn et al., 2005; Triest et al., 2012).

The amount of heavy metals represented by $\mathrm{Cd}, \mathrm{Cu}$ and $\mathrm{Pb}$ did not differ significantly across sites and their concentration did not follow any trend from upstream to downstream. These results agree with previous study that metal concentrations at sites located relatively high up in the catchment were comparable to, or higher than concentrations of these metals downstream. These values are linked to effluent discharge, agricultural and urban run-off, washing and bathing activities by local inhabitants and livestock access to the rivers. In addition degradation of the forest cover and other anthropogenic activities going on inside the forest, atmospheric deposition and geology weathering are potential sources of these metal ions (Dabrowski \& Klerk, 2013).

\subsection{Effect of the Land Use Activities on Soil Quality}

The mean values and standard deviation of soil physico-chemical variables at different sampling sites along the two rivers of Chemosit and Kipsonoi are presented in Table 3 below. The low soil $\mathrm{pH}$ upstream might be due to the presence of slightly higher organic carbon content in the soil. Variability in total organic carbon along the two river

Table 3. Mean concentration levels and standard errors $( \pm)$ of soil properties along Chemosit $\left(^{c}\right)$ and Kipsonoi $\left({ }^{k}\right)$ rivers.

\begin{tabular}{cccc}
\hline Parameters & Upstream & Midstream & Downstream \\
\hline pH & ${ }^{\mathrm{c}} 4.82 \pm 0.02^{\mathrm{a}}$ & $5.45 \pm 0.1^{\mathrm{b}}$ & $5.53 \pm 0.22^{\mathrm{b}}$ \\
& ${ }^{\mathrm{k}} 4.42 \pm 0.06^{\mathrm{a}}$ & $5.61 \pm 0.18^{\mathrm{b}}$ & $5.56 \pm 0.09^{\mathrm{b}}$ \\
Total P (mg/l) & ${ }^{\mathrm{c}} 28.11 \pm 4.83$ & $29.61 \pm 6.17$ & $29.11 \pm 6.17$ \\
& ${ }^{\mathrm{k}} 17.72 \pm 0.87$ & $20.39 \pm 2.367$ & $15.94 \pm 1.22$ \\
TN (\%) & ${ }^{\mathrm{c}} 0.43 \pm 0.13$ & $0.38 \pm 0.09$ & $0.52 \pm 0.18$ \\
& ${ }^{\mathrm{k}} 0.81 \pm-0.04^{\mathrm{b}}$ & $0.32 \pm 0.01^{\mathrm{a}}$ & $0.34 \pm 0.08^{\mathrm{a}}$ \\
TS (mg/l) & ${ }^{\mathrm{c}} 74.11 \pm 18.92$ & $68.33 \pm 19.69$ & $67.22 \pm 20.49$ \\
& ${ }^{\mathrm{k}} 22.6 \pm 4.09^{\mathrm{b}}$ & $16.89 \pm 2.11^{\mathrm{b}}$ & $6.44 \pm 0.15^{\mathrm{a}}$ \\
TK (mg/l) & ${ }^{\mathrm{c}} 758.28 \pm 168.6$ & $812.33 \pm 356.48$ & $736.56 \pm 330.72$ \\
& ${ }^{\mathrm{k}} 490.7 \pm 74.5$ & $313.5 \pm 73.00$ & $271.39 \pm 21.24$ \\
TOC (\%) & ${ }^{\mathrm{c}} 27.09 \pm 4.03$ & $24.20 \pm 1.73$ & $25.74 \pm 1.96$ \\
& ${ }^{\mathrm{k}} 25.36 \pm 0.58$ & $25.93 \pm 0.00$ & $25.5 \pm 0.27$
\end{tabular}

a,b,ab Means with different superscripts in the same row are significantly different at $p<0.05$ (Data analyzed by Tukey's test. 
systems is linked to the reduction in organic material being returned to the soil system due to decreasing vegetation cover downstream and oxidation of soil organic matter as a result of continuous cultivation along the riverbanks, uncontrolled grazing and browsing, loss of organic matter by water erosion and removal of green materials. These results are in agreement with other studies that reported that the soil organic content differed with different land use types (Yimer et al., 2007; Girmay et al., 2008). The higher organic matter content upstream may be attributed to a higher accumulation of organic matter due to high inputs from root biomass (Yimer et al., 2007). Variability in total nitrogen is linked to difference in soil organic matter content, intensities in cultivation and erosion, application of manures, pesticides and fertilizers rich in nitrogen content in the soils (Moges \& Holden, 2008).

The mean values and standard deviation of soil physico-chemical variables at different sampling sites along the two rivers of Chemosit and Kipsonoi are presented in Table 3. In this study, soil pH ranged between 4.42 and 5.56, implying the soils are strongly acidic and suitable for tea production which was consistent with previous studies carried out in tea plantations (Matano et al., 2015). Soil pH was lowest in soils obtained Upstream on both rivers, with significant differences across the sampling sites. Tukey's test showed that soil $\mathrm{pH}$ at upstream differed significantly from soil $\mathrm{pH}$ recorded midstream and downstream of Chemosit and Kipsonoi rivers. The low soil $\mathrm{pH}$ upstream might be due to the presence of slightly higher organic carbon content in the soil. The low soil $\mathrm{pH}$ at the upstream corresponded with a high soil organic carbon at the same site Total organic carbon did not show significance difference, however the levels varied across sampling sites along the Chemosit and Kipsonoi rivers. Variability in total organic carbon along the two river systems is linked to the reduction in organic material being returned to the soil system due to decreasing vegetation cover downstream and oxidation of soil organic matter as a result of continuous cultivation along the riverbanks, uncontrolled grazing and browsing, loss of organic matter by water erosion and removal of green materials. These results are in agreement with other studies that reported that the soil organic content differed with different land use types (Yimer et al., 2007; Girmay et al., 2008). The higher organic matter content upstream along Chemosit river may be attributed to a higher accumulation of organic matter due to high inputs from root biomass (Yimer et al., 2007).

Nitrogen and posphorous are categorized as essential nutrients in the soil for growth and development of plants. Soil nitrogen at the upstream sampling site along Kipsonoi river differed significantly from that of Midstream and downstream sampling sites. There was no significant difference in total nitrogen along Chemosit river. Variability in total nitrogen on both rivers is linked to difference in soil organic matter content, intensities in cultivation and erosion, application of manures, pesticides and fertilizers rich in nitrogen content in the soils (Moges \& Holden, 2008). For example, it is possible that nutrient uptake by crops, leaching during heavy down pours or further removal during plant harvest time could have contributed to the relatively low soil nitrogen content at the midstream (dominated by agricultural land use) of the two rivers compared to other sampling sites (Matano et al., 2015). 
Variability in total phosphorous is related to the application of animal manure and application of diammonium phosphate (DAP) fertilizer on the adjacent farmlands. Lower phosphorous content in the soil along Kipsonoi river as compared to Chemosit river could be related to phosphorous fixation especially in forested areas, crop harvest in agricultural farms and erosion by water (Yimer et al., 2006). Highest content of phosphorous was recorded at the Midstream of Chemosit river majorly dominated by large scale tea production and lowest downstream of Kipsonoi river. According to Matano et al. (2015), land use has a significant effects on soil chemical properties. The levels of soil nutrients ( $\mathrm{P}$ and $\mathrm{N}$ ) can be used to deduce the degree at which a given site is degraged. Potassium levels could be attributed to the relative pumping of potassium from the subsoil by vegetation in the forest land. Lower potassium levels downstream could be attributed to soil degradation and losses by leaching due to reduced vegetation cover (Bohn et al., 2001).

Figure 3 and Figure 4 report the amount of Cadmium, copper and lead in soils along Chemosit and Kipsonoi river. Cadmium showed lowest concentration as compared

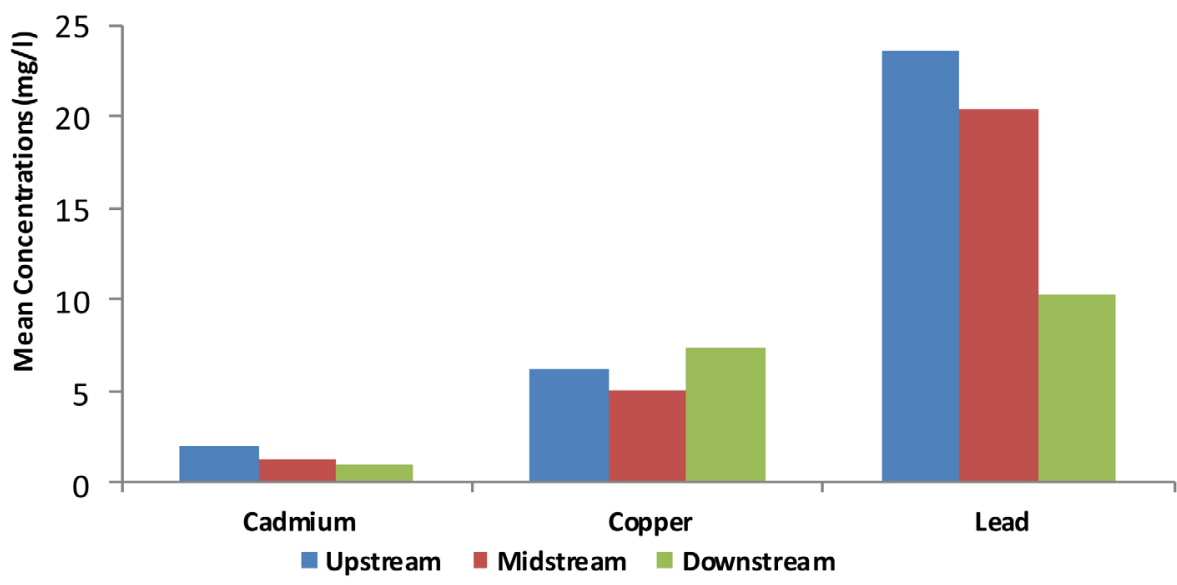

Figure 3. Cadmium, copper and lead content in soils at different sites along Chemosit river.

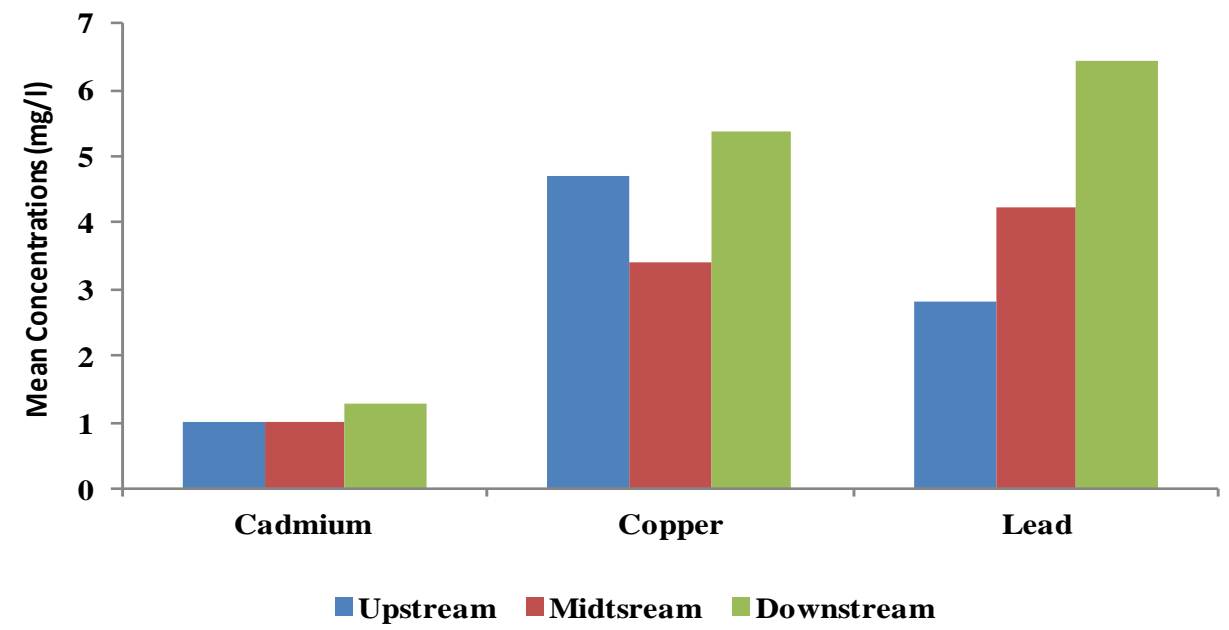

Figure 4. Cadmium, copper and lead content in soils at different sites along Kipsonoi river. 
to copper and lead. However, considering the Canadian soil quality guidelines, all the metals were within the maximum allowable values for agriculture soil; $50-60 \mathrm{mg} / \mathrm{kg}$; $1.4 \mathrm{mg} / \mathrm{kg}$ and $70 \mathrm{mg} / \mathrm{kg}$ ranges for copper, cadmium and lead, respectively (Noorikh et al., 2013).

\section{Conclusion}

Indigenous forest, food crop farming, tree farming, tea growing, livestock keeping and urban settlement were identified as the major land use activities in SWMF. This provided a clear insight on the various land use types along the course of Chemosit and Kipsonoi rivers. Plant species richness decreases and biodiversity disturbance increased from upstream (intact canopy native vegetation), through a mixture of native and exotic species in midstream to livestock grazing and urban settlement downstream. Variation in Total Suspended Solids, $\mathrm{pH}$, Total Nitrogen, Phosphorus and Potassium were associated to different land use activities along the riparian zone. Total Nitrogen and water $\mathrm{pH}$ showed significant sensitivity to land use changes. The results from this study indicate the need for protection of riparian zones, proper land use planning and adoption of sustainable farming systems within the catchment.

\section{References}

Ahearn, D. S., Sheibley, R. W., Dahlgren, R. A., Anderson, M., Johnson, J., \& Tate, K. W. (2005). Land Use and Land Cover Influence on Water Quality in the Last Free-Flowing River Draining the Western Sierra Nevada, California. Journal of Hydrology, 313, 234-247. http://dx.doi.org/10.1016/j.jhydrol.2005.02.038

Andrea, G., Veronique, V., Lorenzo, B., Willy, B., \& Vanrollegham, P. (2009). Model-Based Assessment of Shading Effect by Riparian Vegetation on River Water Quality. Ecological Engineering, 35, 92-104. http://dx.doi.org/10.1016/j.ecoleng.2008.09.014

APHA (1995). Standard Methods for Examination of Water and Wastewater (20th ed.). Washington, DC: American Public Health Association.

APHA (1998). Standard Methods for the Examination of Water and Wastewater. Washington, DC: American Public Health Association, American Water Works Association, and Water Pollution Control Federation.

Bailey, R. G., Busulwa, H., \& Williams, A. (1994). Fish and Aquatic Ecosystems in the Ruwenzori Mountains, Ugandas (p. 106). Darwin Initiative Report, London: Kings College London.

Bohn, H. L., McNeal, B. L., \& O’Connor, G. A. (2001). Soil Chemistry (3rd ed., p. 307). New York: John Wiley \& Sons, Inc.

Buda, A. R., Kleinman, P. J. A., Bryant, R., \& Allen, A. (2010). Impact of Legacy Phosphorus Sources on Diffuse Pollution from Agriculture: Lessons from the Chesapeake Bay Watershed. In: E. van Bochove et al. (Eds.), Diffusepollution and Eutrophication: 14th International Water Association Conference of the Diffuse Pollution Specialist Group (p. 63). IWA Publ., London.

Calamari, D., Akech, M. O., \& Ochumba, P. B. O. (1995). Pollution of Winam Gulf, Lake Victoria, Kenya: A Case Study for Preliminary Assessment. Lakes and Reservoirs: Research and Management, 1, 89-106. http://dx.doi.org/10.1111/j.1440-1770.1995.tb00010.x

Dabrowski, J. M., \& Klerk (2013). An Assessment of the Impact of Different Land Use Activities on Water Quality in the Upper Olifants River Catchment. Water SA, 39, 231-244. 
Enanga, M., Shivoga, W., Maina-Gichaba, C., \& Creed, F. (2011). Observing Changes in Riparian Buffer Strip Soil Properties Related to Land Use Activities in River Njoro Watershed, Kenya. Water and Air Soil Pollution, 218, 587-601. http://dx.doi.org/10.1007/s11270-010-0670-z

FAO (1996). Control of Water Pollution from Agriculture. Written by Ongley, E.D. FAO Irrigation and Drainage Paper, No. 55.

Girmay, G., Singh, B. R., Mitiku, H., Borresen, T., \& Lal, R. (2008). Carbon Stocks in Ethiopian Soils in Relation to Land Use and Soil Management. Land Degradation and Development, 19, 351-367. http://dx.doi.org/10.1002/ldr.844

GoK (2009). Rehabilitation of the Mau Forest Ecosystem, Project Concept by the Interim Coordinating Secretariat, Office of the Prime Minister, September 2009.

Hitimana, J., Kiyiapi, J. L., \& Njunge, J. T. (2004). Forest Structure Characteristics in Disturbed and Undisturbed Sites of Mt. Elgon Moist Lower Montane Forest, Western Kenya. Forest Ecology and Management, 194, 269-291. http://dx.doi.org/10.1016/j.foreco.2004.02.025

Jaetzold, R., \& Schmidt, H. (2009). Farm Management Handbook of Kenya, Vol. 2 (2nd ed.). Ministry of Agriculture, Kenya, in Co-Operation with the Germany Agency for Technical Co-Operation (Gtz).

Kinyanjui (2009). Assessment of Trends in Forest Changes Induced by Human Pressure in Western and South Western Mau Reserves.

Kinyua, A. M., \& Pacini, N. (1991). The Impacts of Pollution on the Ecology of the Nairobi Athi River Systems in Kenya. Journal of Bio-Chemical Physics, 1, 57.

Litman T. (2011). Evaluating Transportation Land Use Impacts Considering the Impacts, Benefits and Costs of Different Land Use Development Patterns. Victoria: Victoria Transport Policy Institute.

Masese, F. O., Raburu, P. O., Mwasi, B. N., \& Etiégni, L. (2011). Effects of Deforestation on Water Resources: Integrating Science and Community Perspectives in the Sondu-Miriu River Basin, Kenya. In Oteng-AmoakoAa (Ed.), New Advances and Contributions to Forestry Research (pp. 1-18). Rijeka: Intech Publishers.

Matano, A. S., Kanangire, C. K., Anyona, D. N., Abuom, P. O., Gelder, F. B., Dida, G. O., Owour, P. O., \& Ofulla, A. V. O. (2015). Effects of Land Use Change Degradation Reflected by Soil Properties along Mara River, Kenya and Tanzania. Open Journal of Soil Science, 5, 20-38. http://dx.doi.org/10.4236/ojss.2015.51003

Mati, B. M., Mutie, S., Gadain, H., Home, P., \& Mtalo, F. (2008). Impacts of land-Use/Cover Changes on the Hydrology of the Transboundary Mara River, Kenya/Tanzania. Lakes and Reservoirs: Research and Management, 13, 169-177. http://dx.doi.org/10.1111/j.1440-1770.2008.00367.x

Mira, O. (2004). Land Use Changes in Central Kenya from the 1950s-A Possibility to Generalise? GeoJournal, 51, 203-209.

Mitsch, W. J., \& Day Jr., J. W. (2006). Restoration of Wetlands in the Mississippi-Ohio-Missouri (MOM) River Basin: Experience and Needed Research. Ecological Engineering, 26, 55-69. http://dx.doi.org/10.1016/j.ecoleng.2005.09.005

Moges, A., \& Holden, N. M. (2008). Soil Fertility in Relation to Slope Position and Agricultural Land Use: A Case Study of Umbulo Catchment in Southern Ethiopia. Environmental Management, 42, 753-763. http://dx.doi.org/10.1007/s00267-008-9157-8

Nelson, D. W., \& Sommers, L. E. (1982). Organic Carbon. In Methods of Soil Analysis. Agronomy Monograph, 9 (2nd ed). Madison USA.

Noorikh, F., Taghreed, H., \& Nadia, H. (2013). Analysis and Assessment of Essential Toxic and Heavy Metals, $\mathrm{pH}$ and Ec in Ishaqiriver and Adjacent Soil. Advances in Physics, Theories and 
Applications, 16.

Okalebo, J. R., Gathua, K. W., \& Woomer, P. L. (2002). Laboratory Methods for Soil and Plant Analysis: A Working Manual (2nd ed.). Nairobi: Tropical Soil Biology and Fertility Program, Nairobi.

Olson, J. M., \& Maitima, J. M. (2006). Sustainable Intensification of Mixed Crop-Livestock Systems, Land Use Change Impacts and Dynamics (Lucid). Nairobi: International Livestock Research Institute.

Ouma, K. O., Mungai, N. W., \& Kitaka, N. (2013). Temporal Variation of Sedimentation from Surface Runoff from Agricultural Land Uses in Sondu-Miriu Basin, Kenya. Research Journal of Environmental and Earth Sciences, 5, 577-590.

Stohlgren, T. J., Falkner, M. B., \& Schell, L. D. (1995). A Modified-Whittaker Nested Vegetation Sampling Method. Plant Ecology, 117, 113-121. http://dx.doi.org/10.1007/BF00045503

Triest, L., Lungayia, H., Ndiritu, G., \& Beyene, A. (2012). Epilithic Diatoms as Indicators in Tropical African Rivers (Lake Victoria Catchment). Hydrobiologia, 695, 343-360.

World Health Organization (2000). Guidelines for Drinking Water Quality. New York: World Health Publication.

Wu, Q., Li, H.-R., Wang, J., Paulussen, Y., He, M., Wang, B., \& Wang, Z. (2006). Monitoring and Predicting Land Use Change in Beijing Using Remote Sensing and GIS. Landscape and Urban Planning, 78, 322-333. http://dx.doi.org/10.1016/j.landurbplan.2005.10.002

Yimer, F., Ledin, S., \& Abdelkadir, A. (2007). Changes in Soil Organic Carbon and Total Nitrogen Contents in Three Adjacent Land Use Types in the Bale Mountains, South-Eastern Highlands of Ethiopia. Forest Ecology and Management, 242, 337-342.

http://dx.doi.org/10.1016/j.foreco.2007.01.087

Submit or recommend next manuscript to SCIRP and we will provide best service for you:

Accepting pre-submission inquiries through Email, Facebook, LinkedIn, Twitter, etc.

A wide selection of journals (inclusive of 9 subjects, more than 200 journals)

Providing 24-hour high-quality service

User-friendly online submission system

Fair and swift peer-review system

Efficient typesetting and proofreading procedure

Display of the result of downloads and visits, as well as the number of cited articles

Maximum dissemination of your research work

Submit your manuscript at: http://papersubmission.scirp.org/ 